\title{
A comparison of the effect of the application of kinesiology taping to the use of upper limb compression products in the second phase of treating lymphoedema in patients after mastectomy
}

\section{Porównanie oddziaływania aplikacji kinesiology taping z zastosowaniem wyrobów uciskowych kończyn górnych w II fazie leczenia obrzęku limfatycznego u pacjentek po mastektomii}

\author{
Anna M. Opuchlik ${ }^{1,2}$, Małgorzata Biskup¹, Marcin Solakiewicz¹, Ewelina Kamińska-Gwóźdź3 , Tomasz Ridan4, \\ Anna Włoch ${ }^{1}$, Anna Maria Lipińska ${ }^{1,5}$ \\ ${ }^{1}$ Rehabilitation Department, The Holycross Cancer Center, Kielce, Poland \\ Head of Centre: Stanisław Góźdź MD, PhD \\ 2Department of Physiotherapy, Faculty of Physical Education and Tourism, Holycross University, Kielce, Poland \\ Head of University: Prof. Janusz Zdebski PhD \\ ${ }^{3}$ Department of Neurology, Neurological Rehabilitation and Kinesitherapy, Institute of Physiotherapy, Faculty of Health Sciences, \\ Jan Kochanowski University, Kielce, Poland \\ Head of Department: Prof. Jacek Wilczyński PhD \\ ${ }^{4}$ Kinesitherapy Unit, Department of Physiotherapy, University of Physical Education, Krakow, Poland \\ Head of Department: Jakub Szczechowicz PhD \\ ${ }^{5}$ Department of Organ of Hearing and Balance Rehabilitation, Institute of Physiotherapy, Faculty of Health Sciences, \\ Jan Kochanowski University, Kielce, Poland \\ Head of Department: Prof. Stanisław Bień MD, PhD
}

Key words: mastectomy, lymphoedema, complex decongestive therapy, kinesiology taping.

Słowa kluczowe: obrzęk limfatyczny, kompleksowa terapia udrażniająca, kinesiology taping.

\begin{abstract}
Aim of the research: The aim of this study was to answer the question of whether wearing compression products on the upper limb in the second phase of complex decongestive therapy (CDT) can be replaced with lymphatic application of kinesiology taping. The importance of antiedematous prophylaxis and the impact of complementary treatment on the results of physiotherapeutic management were assessed.

Material and methods: Retrospective analysis was applied in 80 women after mastectomy treated for lymphoedema in the Holycross Cancer Centre in Kielce. The method CDT was applied in all the patients in phase I. In phase II, 50 (62\%) women used compression sleeves in everyday life, and lymphatic applications of Kinesiology Taping (KT) were introduced in $30(38 \%)$ patients. The research included the following: interview, linear measurement of the upper limb circumferences, palpation of tissues, and assessment of pain; statistical analysis in terms of these parameters was also performed.

Results: Application of antiedematous prophylaxis was confirmed by $65 \%$ of the women, and complementary treatment was introduced in $75 \%$ of the patients from both groups. After phase I of the CDT a significant reduction in the circumferences of the limb in patients from both groups was demonstrated. Comparable results were observed after phase II, but in the second group the circumferences underwent a slight increase. After phases I and II of the therapy there was a beneficial change in the consistency, from hard into soft in both groups.

Conclusions: The applied antiedematous prophylaxis was not essential in the course of the treatment. Introduction of radiotherapy had a significant impact on the state of the oedema. Application of physiotherapy resulted in an improvement in the oedema parameters in all the patients after phase I of the therapy. The results were maintained in the phase II in the women who used compression sleeves. Applications of KT did not provide an improvement of the state of the limb circumferences in phase II, but they affected the maintenance of the right oedema consistency and caused a reduction in pain.
\end{abstract}

\section{Streszczenie}

Wprowadzenie: Wtórny obrzęk limfatyczny kończyn górnych jest jednym z późnych powikłań u pacjentek po radykalnym leczeniu raka gruczołu piersiowego. 
Cel pracy: Uzyskanie odpowiedzi na pytanie, czy noszenie na kończynie górnej wyrobów uciskowych w fazie II kompleksowej fizycznej terapii udrażniającej (KFTU) można zastąpić aplikacjami limfatycznymi kinesiology taping (KT).

Materiał i metody: Analizie retrospektywnej poddano 80 kobiet po mastektomii leczonych z powodu obrzęku limfatycznego w Świętokrzyskim Centrum Onkologii. U wszystkich pacjentek zastosowano w fazie I metodę KFTU. W fazie II $50(62 \%)$ kobiet stosowało na co dzień rękawy uciskowe, a u 30 (38\%) wprowadzono aplikacje limfatyczne KT. Badania obejmowały wywiad, pomiary linijne obwodów kończyn, palpację tkanek i ocenę bólu. Wykonano analizę statystyczną w zakresie tych parametrów.

Wyniki: Po I etapie KFTU wykazano redukcję obwodów kończyny u chorych z obu grup. Porównywalne wyniki zauważono po II fazie, ale w drugiej grupie obwody nieznacznie się zwiększyły. Po I i II fazie terapii nastąpiła korzystna zmiana konsystencji z twardej na miękką w obu grupach.

Wnioski: Zastosowanie fizjoterapii spowodowało istotną poprawę parametrów obrzęku u wszystkich chorych po I fazie terapii. Aplikacje KT nie zapewniły poprawy stanu obwodów kończyny w II fazie, ale wpłynęły na zachowanie odpowiedniej konsystencji obrzęku i zmniejszenie bólu.

\section{Introduction}

Secondary lymphoedema of the upper limbs is one of the late complications in patients after radical treatment of breast cancer. One of the methods of conservative treatment of this chronic disease available in Poland is complex decongestive therapy (CDT). Another method used in the treatment of lymph oedema is kinesiology taping (KT). Both methods are used in an increasing number of cancer centres and other health facilities in Poland. The results of numerous clinical trials [1-9] confirm the effectiveness of the CDT method. Observations of patients are not always based on long-term assessment of the treatment effects. Achieving good results of therapy in the form of a reduction in the circumferences or improvement of the tissue consistency after stage I of the treatment should be maintained for a further period. Achieving stability and lack of progression of the advanced oedema sizes for a period of 6 to 12 months, however, is a challenge for the physiotherapeutic team. Patients do not always follow the recommendations and reluctantly wear compression products in phase II of the treatment. Patients who believe that the systematic use of compression sleeves is troublesome and not very comfortable look for alternative methods. Tsai et al. [10] suggested replacing the uncomfortable garment with KT. They conducted a three-month observation in 41 patients with lymphoedema, who were divided into two groups. In the first group, a method of CDT with the use of bandages was applied, and in the other they were replaced with lymphatic applications of KT. They proved that the KT can replace the uncomfortable compression garments and provide patients with a better quality of life. In turn, Ciesielska et al. [11] and Lipińska et al. [12] compared the effects of manual lymphatic drainage conducted in women after mastectomy with kinesiotaping of the upper limb. Both studies showed a significant reduction in the oedema under the influence of KT applications, and better results were obtained in these groups. However, Pop et al. [13] analysed patients with lymphoedema after a radical treatment of breast cancer, in which KT applications combined with motion exer- cises and education were used. In the majority of the examined women very good results were obtained for oedema symptoms reduction and improved arm mobility ranges.

To verify these statements, the patients' own material was analysed to determine whether lymphatic applications of KT can replace compression products, providing patients with stabilisation or improvement of the previously obtained results of the treatment.

It is considered that the causes of lymphoedema are as follows: mechanical damage to the lymph nodes and vessels of the armpit, chronic inflammatory processes, ionising irradiation, or limitation of physical activity of the limb and its excessive overloading with physical effort $[14,15]$. Risk factors include constitutional factors, analysed on the basis of somatic parameters, such as high body mass and high values of the indexes: body mass index (BMI), waist-to-hip ratio (WHR), Quetelet, Rohrer, and Pignet-Verwaeck [16]. Establishing a mechanism that is decisive at the origin of this complication can be imprecise, and sometimes impossible. Therefore, ensuring that patients after a radical surgery of the breast are aware of the dangers of lymphoedema should be an important part of the treatment. For this purpose, education of patients and getting them acquainted with the principles of antiedematous prophylaxis are introduced. However, these actions are not always implemented by medical personnel. Dziura and Grądalski [17] observed a low level of education of women after mastectomy, as well as their failure to follow the recommendations they received. In the authors' own study they assessed whether the patients used the knowledge on preventing lymphoedema and what role this procedure played during the treatment. Because radiation is considered to be a common cause of oedema $[14,15,18$, 19], an analysis of the significance of this therapy in the obtained results of the physiotherapy treatment was carried out.

\section{Aim of the research}

The aim of this research was to obtain an answer to the question of whether wearing uncomfortable 
compression products on the upper limb in the second phase of CDT can be replaced with lymphatic application of KT. It was assessed whether or not the applied antiedematous prophylaxis is important in the course of the therapy. The impact of the implemented complementary treatment on the results of physiotherapeutic management was compared.

\section{Material and methods}

The study was carried out on a group of $80(100 \%)$ women aged 60 to 80 years (average 60 years old), after mastectomy, treated for lymphoedema in the Rehabilitation Department of the Holycross Cancer Centre in Kielce in the period from January to June, 2012. In all the patients the CDT method - phase I was applied for a period of 2-3 weeks. The method involved carrying out daily manual lymphatic drainage (Vodder technique), skin care (applying a caring agent before compression), and compression with the use of applied layers of not very elastic bandages, as well as gymnastics restoring patency, based on active, dynamic movements of the limb (concentric and eccentric contraction) conducted in drainage positions. In phase II - for a month after the end of the first stage, 50 (62\%) women - the group of CDT + C - used compression sleeves in everyday life, and in 30 (38\%) patients in the control group - CDT + KT - lymphatic application of KT were introduced (compression was applied only in phase I, but not during the time of using KT). The size and the compression ratio of compression sleeves were selected according to the circumferences and the length of the upper limb. In lymphatic applications with the tape K-Active Nitto Denko, the 'Fork' technique was used, in which a 5-centimetre-wide plaster was divided into four equal strips. At the length of $5 \mathrm{~cm}$, the uncut part was the base, which was at the same time the beginning of the application. The base was stuck in the site of local lymph nodes or along lymph vessels in the direction in accordance with the flow of lymph. Kinesiology taping tapes were applied on the skin for a period of 4-5 days, and after their use the next application took place. All the patients were interviewed for their personal data, the cancer treatment, the applied antiedematous prophylaxis, the time and causes of oedema, the amount of infection (rose), and the presence of pain before and after the treatment. Preventing the occurrence of lymphoedema was associated with self-reliant and systematic undertaking by the patients of self-massage of the limb, physical exercise, breathing exercises, and putting the limb in a high position, as well as its protection against mechanical injuries or overloads. Physical examination included the following: a visual assessment of the skin condition (colour, keratosis, fibrosis), linear measurements of the upper limbs circumferences, and palpable assessment of the consistency of the limb tissues, which were performed before and after particular phases of the physiotherapy management. Linear measurements were performed with the use of a measuring tape at seven points of the upper limb. A difference of $1.5 \mathrm{~cm}$ between the circumferences of at least two points was adopted as a criterion for the diagnosis of lymphoedema. Palpable assessment of tissues consisted of applying the Stemmer test (sign) on the dorsal, proximal part of a phalanx of the II and III finger and the 'hole' test - a hollow of a thumb in the area of tissue of the swollen limb [20, 21]. A positive Stemmer sign meant a lack of the possibility to elevate the skin over the fascia, and a negative one meant the correct skin elasticity in relation to the fascia. In the 'hole' test, a hollow quickly disappearing from the skin was assessed as level I of lymphoedema (soft or plastic, reversible). In the case of a long-lasting sign on the skin (fibrosclerosis) and the impossibility of withdrawing the changes under the influence of the limb elevation, the oedema was assessed at level II (spontaneously-irreversible, hard). The skin condition, which makes the deformation impossible in this test, testified the hard oedema, irreversible with sclerotic changes characteristic of level III of oedema (lymphatic elephantiasis) [18, 22, 23].

\section{Statistical analysis}

For the linear circumferences of the limb in the course of the therapy basic statistics were determined: average, standard deviation, median, quartiles and min. and max. Frequencies and percentages were determined for the analysis of qualitative characteristics (the degree of tissue consistency of the limb and pain). The following statistical methods were applied: $t$-Student's test, two-factor analysis of variance, and $\chi^{2}$ test. Statistical calculations were done with the use of the MedCalc Statistical Software version 13.2.0 (MedCalc Software bvba, Ostend, Belgium; http://www. medcalc.org, 2014), licensed to the Holycross Cancer Centre in Kielce.

\section{Results}

Application of antiedematous prophylaxis was confirmed by 52 (65\%) women from both groups, but this was not important for the degree of oedema or the course of the treatment. Chemotherapy and radiotherapy were introduced in the treatment of breast cancer in $60(75 \%)$ patients. In most measuring points of the upper limb circumferences, a statistically significant influence of radiotherapy on different phases of the treatment was noticed. After phase I of CDT, a significant reduction in the limb circumferences in patients from both groups was demonstrated. Comparable results were observed after phase II of the treatment, but in the CDT + KT group the circumferences underwent a slight increase, which was not significant. After phases I and II of the therapy there 
was a beneficial change in the consistency, from hard to soft, in women from both groups.

\section{Discussion}

Lymphatic oedema occurred more often in the area of the upper left limb in the CDT $+\mathrm{C}$ group in 29 patients (58\%), and in the CDT + KT group in $22(73 \%)$ patients. Antioedematous prophylaxis was applied by most of the women in the surveyed groups: in the first group - $32(64 \%)$ and in the control group - $20(66.5 \%)$. In spite of the practical implementation of the prevention principles into daily activities, lymphoedema occurred in the studied patients. Complementary therapy in the form of chemotherapy and radiotherapy was introduced in the treatment of breast cancer in $60(75 \%)$ patients. Oedema occurred in $14(28 \%)$ patients in the study group in the period of 1.5 years after the performed surgery. However, $14(46.5 \%)$ patients from the control group reported that oedema occurred in them in the period from 0.5 to 1 year after the surgery. The majority of women in both groups - 18 (36\%) in the CDT + C group and $12(40 \%)$ in the CDT + KT group - found that lymphoedema occurred spontaneously, without an apparent cause. Another factor causing its occurrence was radiotherapy - in $11(22 \%)$ patients from the first group and in 7 (23.3\%) from the other group. The same number of women from both groups stated that the oedema was due to excessive load of the limb with physical effort. Few patients mentioned the operation $-7(14 \%)$ in the CDT + C group and $2(6 \%)$ in the group CDT + KT and chemotherapy, $3(6 \%)$ in the first group and $2(6 \%)$ in the other group - as a trigger for the creation of this complication. Before starting the treatment, level II of the advancement of oedema was diagnosed, because the average circumferences of the limb with oedema were very different from the limb on the healthy side in women from both groups, especially in the area of the arm and forearm (Table 1).

However, the consistency of oedema before the undertaken physiotherapy management was most often assessed as hard in 19 (38\%) patients from the test group and as plastic in $13(43.3 \%)$ women in the comparison group (Figure 1). In the first group, in $17(34 \%)$ patients soft oedema was diagnosed and in $14(28 \%)$ it was plastic. In the CDT + KT group oedema with a hard consistency also appeared - in 11 (36.6\%) patients and soft - only in $6(20 \%)$ women.

It was analysed whether the patients who followed the principles of the anti-oedematous prophylaxis obtained better or worse results in the course of the physiotherapeutic management. We assessed the importance of prevention in the obtained state of the limb circumferences in seven measuring points, in different phases of the treatment (Table 2). In the stages of the therapy, and regardless of whether the patients applied antiedematous prophylaxis or not, the same degree of improvement in the upper limb circumference reduction was achieved. Only at the circumference of the elbow joint and metacarpal in the study group was the importance of prevention in the course of the therapy observed. Measures preventing oedema had no significant statistical influence on the state of the limb circumferences during physiotherapy.

Because the majority of the women from the first group - 39 (78\%) - and 22 (73\%) from the second group during the treatment of breast cancer underwent radiotherapy, its impact on the course of the physiother-

Table 1. Average differences between the circumferences of the limb with oedema in relation to the circumferences of the healthy limb in women from the groups before the treatment

\begin{tabular}{|c|c|c|c|c|c|}
\hline $\begin{array}{l}\text { Measurement level of the } \\
\text { upper limb circumference }\end{array}$ & Group & $\begin{array}{l}\text { Healthy limb } \\
{[\mathrm{cm}]}\end{array}$ & $\begin{array}{l}\text { The limb with } \\
\text { oedema }[\mathrm{cm}]\end{array}$ & $\begin{array}{l}\text { Difference } \\
\quad[\mathrm{cm}]\end{array}$ & $\begin{array}{l}P \text {-value for } \\
\text { a } t \text {-Student test }\end{array}$ \\
\hline $10 \mathrm{~cm}$ below the arm & $\begin{array}{l}\mathrm{CDT}+\mathrm{C} \\
\mathrm{CDT}+\mathrm{KT}\end{array}$ & $\begin{array}{l}33 \\
31\end{array}$ & $\begin{array}{c}35 \\
32.8\end{array}$ & $\begin{array}{c}2 \\
1.8\end{array}$ & $\begin{array}{l}<0.001 \\
<0.001\end{array}$ \\
\hline $10 \mathrm{~cm}$ above the elbow joint & $\begin{array}{l}\mathrm{CDT}+\mathrm{C} \\
\mathrm{CDT}+\mathrm{KT}\end{array}$ & $\begin{array}{c}29.8 \\
28\end{array}$ & $\begin{array}{c}33.2 \\
31\end{array}$ & $\begin{array}{c}3.4 \\
3\end{array}$ & $\begin{array}{l}<0.001 \\
<0.001\end{array}$ \\
\hline Elbow joint & $\begin{array}{l}C D T+C \\
C D T+K T\end{array}$ & $\begin{array}{c}26.3 \\
25\end{array}$ & $\begin{array}{l}29 \\
27\end{array}$ & $\begin{array}{c}2.7 \\
2\end{array}$ & $\begin{array}{l}<0.001 \\
<0.001\end{array}$ \\
\hline $10 \mathrm{~cm}$ below the elbow & $\begin{array}{l}\mathrm{CDT}+\mathrm{C} \\
\mathrm{CDT}+\mathrm{KT}\end{array}$ & $\begin{array}{l}25 \\
23\end{array}$ & $\begin{array}{c}28 \\
25.5\end{array}$ & $\begin{array}{c}3 \\
2.5\end{array}$ & $\begin{array}{l}<0.001 \\
<0.001\end{array}$ \\
\hline $3 \mathrm{~cm}$ before the wrist & $\begin{array}{l}\mathrm{CDT}+\mathrm{C} \\
\mathrm{CDT}+\mathrm{KT}\end{array}$ & $\begin{array}{l}18 \\
17\end{array}$ & $\begin{array}{c}20 \\
18.4\end{array}$ & $\begin{array}{c}2 \\
1.4\end{array}$ & $\begin{array}{l}<0.001 \\
<0.001\end{array}$ \\
\hline Radial-carpal joint & $\begin{array}{l}\mathrm{CDT}+\mathrm{C} \\
\mathrm{CDT}+\mathrm{KT}\end{array}$ & $\begin{array}{l}17 \\
16\end{array}$ & $\begin{array}{l}17.9 \\
17.3\end{array}$ & $\begin{array}{l}0.9 \\
1.3\end{array}$ & $\begin{array}{l}0.005 \\
0.002\end{array}$ \\
\hline Metacarpus & $\begin{array}{l}\mathrm{CDT}+\mathrm{C} \\
\mathrm{CDT}+\mathrm{KT}\end{array}$ & $\begin{array}{c}19 \\
18.4\end{array}$ & $\begin{array}{l}19.5 \\
19.1\end{array}$ & $\begin{array}{l}0.5 \\
0.7\end{array}$ & $\begin{array}{l}<0.001 \\
<0.001\end{array}$ \\
\hline
\end{tabular}




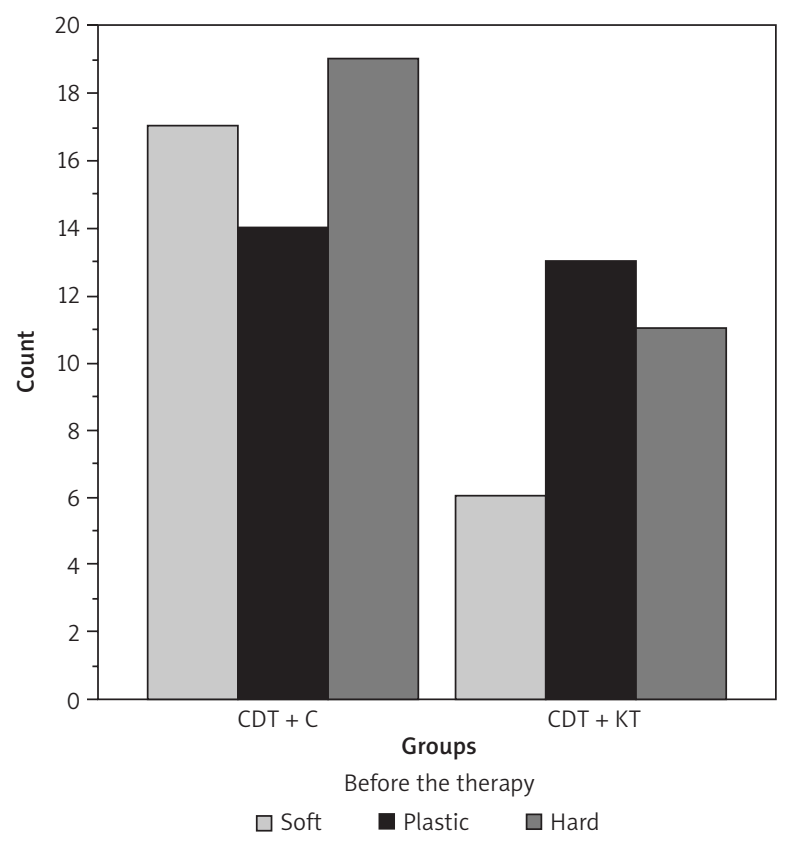

Figure 1. The assessment of the tissue consistency of the limb with oedema prior to the treatment

apy management was evaluated. The achieved results in the reduction of individual circumferences of the limb during the stages of the therapy in patients with previously conducted exposure to radiation and in patients who did not have this treatment were compared (Table 3). Irradiation had a statistically significant effect on the results achieved in reducing the circumfer- ences of the limb affected with oedema, particularly in the area of the forearm and hand.

The same analysis was performed with regard to 46 (92\%) women from the first group, and 24 (80\%) from the other, who were subjected to chemotherapy during the anticancer therapy. In particular stages of the treatment, and irrespective of the applied treatment system, the same degree of improvement in terms of reduction of the upper limb circumferences was achieved. Chemotherapy was not a statistically significant factor determining the treatment of lymphoedema.

In the evaluation of the limb circumferences in seven measuring points particular stages of the treatment in relation to each other (before the therapy and after the first phase, and after phases I and II) were compared. All average circumferences in the women in both groups were significantly reduced after the applied CDT - phase I. In Stage II of the treatment in the patients who for one month after ending CDT used compression sleeves (the CDT $+\mathrm{C}$ group) there was a further statistically significant reduction in all the measuring points of the limb circumferences. Such an improvement was not obtained in the women with lymphatic application of KT; most of the circumferences increased slightly, although this was not statistically significant (Table 4). In patients from this group stabilisation in terms of the limb circumferences was observed, which demonstrates the beneficial impact of the treatment on the state of oedema.

Examination of the tissue consistency after stage I of the therapy in the first group of patients (CDT $+\mathrm{C})$ showed a positive change in comparison with the assessment carried out prior to the treatment. The limb

Table 2. Circumferences of the upper limb with oedema in the course of the therapy with respect to the applied antioedematous prophylaxis

\begin{tabular}{|lccc|}
\hline $\begin{array}{l}\text { Measurement level of the } \\
\text { upper limb circumference }\end{array}$ & Group & \multicolumn{2}{c|}{$\begin{array}{c}P \text {-value } \\
\text { Two-factor analysis of variance }\end{array}$} \\
\cline { 2 - 3 } $10 \mathrm{~cm}$ below the arm & & $\begin{array}{c}\text { 'Phase therapy' } \\
\text { factor }\end{array}$ & $\begin{array}{c}\text { 'Anti-oedematous } \\
\text { prophylaxis' factor }\end{array}$ \\
$10 \mathrm{~cm}$ above the elbow joint & $\mathrm{CDT}+\mathrm{C}$ & 0.014 & 0.430 \\
& $\mathrm{CDT}+\mathrm{KT}$ & 0.010 & 0.249 \\
Elbow joint & $\mathrm{CDT}+\mathrm{C}$ & 0.028 & 0.592 \\
& $\mathrm{CDT}+\mathrm{KT}$ & 0.235 & 0.222 \\
$10 \mathrm{~cm}$ below the elbow & $\mathrm{CDT}+\mathrm{C}$ & $<0.001$ & 0.321 \\
& $\mathrm{CDT}+\mathrm{KT}$ & 0.114 & 0.216 \\
$3 \mathrm{~cm}$ before the wrist & $\mathrm{CDT}+\mathrm{C}$ & 0.002 & 0.050 \\
& $\mathrm{CDT}+\mathrm{KT}$ & 0.239 & 0.671 \\
Radial-carpal joint & $\mathrm{CDT}+\mathrm{C}$ & 0.002 & 0.014 \\
& $\mathrm{CDT}+\mathrm{KT}$ & 0.245 & 0.838 \\
Metacarpus & $\mathrm{CDT}+\mathrm{C}$ & 0.002 & $<0.001$ \\
& $\mathrm{CDT}+\mathrm{KT}$ & 0.100 & 0.513 \\
\hline
\end{tabular}


Table 3. Circumferences of the upper limb with oedema in the course of the therapy with respect to the applied radiation

\begin{tabular}{|c|c|c|c|}
\hline \multirow[t]{2}{*}{$\begin{array}{l}\text { Measurement level of the upper limb } \\
\text { circumference }\end{array}$} & \multirow[t]{2}{*}{ Group } & \multicolumn{2}{|c|}{$\begin{array}{c}P \text {-value } \\
\text { Two-factor analysis of variance }\end{array}$} \\
\hline & & Phase therapy factor & Radiotherapy $(\mathrm{T} / \mathrm{N})$ factor \\
\hline $10 \mathrm{~cm}$ below the arm & $\begin{array}{c}\mathrm{CDT}+\mathrm{C} \\
\mathrm{CDT}+\mathrm{KT}\end{array}$ & $\begin{array}{l}0.031 \\
0.127\end{array}$ & $\begin{array}{l}0.037 \\
0.215\end{array}$ \\
\hline $10 \mathrm{~cm}$ above the elbow joint & $\begin{array}{c}\mathrm{CDT}+\mathrm{C} \\
\mathrm{CDT}+\mathrm{KT}\end{array}$ & $\begin{array}{l}0.043 \\
0.222\end{array}$ & $\begin{array}{l}0.040 \\
0.273\end{array}$ \\
\hline Elbow joint & $\begin{array}{c}\mathrm{CDT}+\mathrm{C} \\
\mathrm{CDT}+\mathrm{KT}\end{array}$ & $\begin{array}{c}<0.001 \\
0.171\end{array}$ & $\begin{array}{l}0.004 \\
0.684\end{array}$ \\
\hline $10 \mathrm{~cm}$ below the elbow & $\begin{array}{c}\mathrm{CDT}+\mathrm{C} \\
\mathrm{CDT}+\mathrm{KT}\end{array}$ & $\begin{array}{l}0.005 \\
0.271\end{array}$ & $\begin{array}{l}<0.001 \\
0.002\end{array}$ \\
\hline $3 \mathrm{~cm}$ before the wrist & $\begin{array}{c}\mathrm{CDT}+\mathrm{C} \\
\mathrm{CDT}+\mathrm{KT}\end{array}$ & $\begin{array}{l}0.010 \\
0.210\end{array}$ & $\begin{array}{l}<0.001 \\
<0.001\end{array}$ \\
\hline Radial-carpal joint & $\begin{array}{c}\mathrm{CDT}+\mathrm{C} \\
\mathrm{CDT}+\mathrm{KT}\end{array}$ & $\begin{array}{c}<0.002 \\
0.100\end{array}$ & $\begin{array}{l}0.001 \\
0.513\end{array}$ \\
\hline Metacarpus & $\begin{array}{c}\mathrm{CDT}+\mathrm{C} \\
\mathrm{CDT}+\mathrm{KT}\end{array}$ & $\begin{array}{l}0.001 \\
0.019\end{array}$ & $\begin{array}{l}0.015 \\
0.033\end{array}$ \\
\hline
\end{tabular}

Table 4. Average circumferences of the treated limbs before and after phase I, and after stages I and II of the physiotherapeutic management

\begin{tabular}{|c|c|c|c|c|c|c|c|}
\hline $\begin{array}{l}\text { Measurement } \\
\text { level of the } \\
\text { upper limb } \\
\text { circumference }\end{array}$ & Group & $\begin{array}{l}\text { The } \\
\text { arithmetic } \\
\text { mean } \\
\text { before the } \\
\text { treatment } \\
{[\mathrm{cm}]}\end{array}$ & $\begin{array}{l}\text { The } \\
\text { arithmetic } \\
\text { mean after } \\
\text { phase I } \\
\text { of the } \\
\text { treatment } \\
\text { [cm] }\end{array}$ & $\begin{array}{c}P \text {-value for } \\
\text { a } t \text {-Student } \\
\text { test }\end{array}$ & $\begin{array}{l}\text { The } \\
\text { arithmetic } \\
\text { mean after } \\
\text { phase I } \\
\text { [cm] }\end{array}$ & $\begin{array}{l}\text { The } \\
\text { arithmetic } \\
\text { mean after } \\
\text { phase II } \\
\text { of the } \\
\text { treatment } \\
\text { [cm] }\end{array}$ & $\begin{array}{l}P \text {-value for } \\
\text { a } t \text {-Student } \\
\text { test }\end{array}$ \\
\hline $\begin{array}{l}10 \mathrm{~cm} \text { below } \\
\text { the arm }\end{array}$ & $\begin{array}{l}\mathrm{CDT}+\mathrm{C} \\
\mathrm{CDT}+\mathrm{KT}\end{array}$ & $\begin{array}{c}35 \\
32.8\end{array}$ & $\begin{array}{l}33.9 \\
31.1\end{array}$ & $\begin{array}{l}<0.001 \\
<0.001\end{array}$ & $\begin{array}{l}33.9 \\
31.1\end{array}$ & $\begin{array}{l}32.9 \\
30.9\end{array}$ & $\begin{array}{l}<0.001 \\
0.2553\end{array}$ \\
\hline $\begin{array}{l}10 \mathrm{~cm} \text { above } \\
\text { the elbow joint }\end{array}$ & $\begin{array}{c}\mathrm{CDT}+\mathrm{C} \\
\mathrm{CDT}+\mathrm{KT}\end{array}$ & $\begin{array}{c}33.2 \\
31\end{array}$ & $\begin{array}{l}31.9 \\
29.4\end{array}$ & $\begin{array}{l}<0.001 \\
<0.001\end{array}$ & $\begin{array}{l}31.9 \\
29.4\end{array}$ & $\begin{array}{l}31.6 \\
29.9\end{array}$ & $\begin{array}{l}0.0125 \\
0.0169\end{array}$ \\
\hline Elbow joint & $\begin{array}{c}\mathrm{CDT}+\mathrm{C} \\
\mathrm{CDT}+\mathrm{KT}\end{array}$ & $\begin{array}{l}29 \\
27\end{array}$ & $\begin{array}{l}27.6 \\
25.7\end{array}$ & $\begin{array}{l}<0.001 \\
<0.001\end{array}$ & $\begin{array}{l}27.6 \\
25.7\end{array}$ & $\begin{array}{l}27.1 \\
25.9\end{array}$ & $\begin{array}{l}0.006 \\
0.2811\end{array}$ \\
\hline $\begin{array}{l}10 \mathrm{~cm} \text { below } \\
\text { the elbow }\end{array}$ & $\begin{array}{l}\mathrm{CDT}+\mathrm{C} \\
\mathrm{CDT}+\mathrm{KT}\end{array}$ & $\begin{array}{c}28 \\
25.5\end{array}$ & $\begin{array}{l}26.5 \\
24.6\end{array}$ & $\begin{array}{l}<0.001 \\
<0.001\end{array}$ & $\begin{array}{l}26.5 \\
24.6\end{array}$ & $\begin{array}{l}26.1 \\
24.8\end{array}$ & $\begin{array}{l}0.0122 \\
0.2084\end{array}$ \\
\hline $\begin{array}{l}3 \mathrm{~cm} \text { before } \\
\text { the wrist }\end{array}$ & $\begin{array}{l}\mathrm{CDT}+\mathrm{C} \\
\mathrm{CDT}+\mathrm{KT}\end{array}$ & $\begin{array}{c}20 \\
18.4\end{array}$ & $\begin{array}{c}19 \\
17.6\end{array}$ & $\begin{array}{l}<0.001 \\
<0.001\end{array}$ & $\begin{array}{c}19 \\
17.6\end{array}$ & $\begin{array}{l}18.7 \\
17.7\end{array}$ & $\begin{array}{l}0.0448 \\
0.9456\end{array}$ \\
\hline $\begin{array}{l}\text { Radial-carpal } \\
\text { joint }\end{array}$ & $\begin{array}{l}\mathrm{CDT}+\mathrm{C} \\
\mathrm{CDT}+\mathrm{KT}\end{array}$ & $\begin{array}{l}17.9 \\
17.3\end{array}$ & $\begin{array}{c}17 \\
16.4\end{array}$ & $\begin{array}{l}0.0003 \\
0.0100\end{array}$ & $\begin{array}{c}17 \\
16.4\end{array}$ & $\begin{array}{l}16.9 \\
16.4\end{array}$ & $\begin{array}{l}0.1240 \\
0.8953\end{array}$ \\
\hline Metacarpus & $\begin{array}{c}\mathrm{CDT}+\mathrm{C} \\
\mathrm{CDT}+\mathrm{KT}\end{array}$ & $\begin{array}{l}19.5 \\
19.1 \\
\end{array}$ & $\begin{array}{c}19 \\
18.5 \\
\end{array}$ & $\begin{array}{l}<0.001 \\
<0.001\end{array}$ & $\begin{array}{c}19 \\
18.5 \\
\end{array}$ & $\begin{array}{l}18.7 \\
18.4 \\
\end{array}$ & $\begin{array}{l}0.0002 \\
0.4138 \\
\end{array}$ \\
\hline
\end{tabular}

tissue became clearly soft, which means the improvement of the state of oedema. This feature was observed in 43 (85\%) patients. Further improvement occurred under the influence of wearing compression sleeves, because after phase II of the treatment oedema of soft consistency was observed in 47 (94\%) patients (Figure 2).

Similar results were achieved in the comparison group. Before the therapy the soft nature of oedema was observed in $6(20 \%)$ women, and after phase I of the treatment it was observed in 25 (83\%). Later the improvement occurred after the completion of phase II, where a soft consistency was found in 29 (96.5\%) of the examined patients who used the KT (Figure 3).

The vast minority of the women reported pain prior to the treatment in the area of the treated limb $-16(32 \%)$ in the group CDT + C and 12 (40\%) in the group CDT $+\mathrm{KT}$. In the first group the symptoms of pain in the limb were noticed only in $1(2 \%)$ patient 


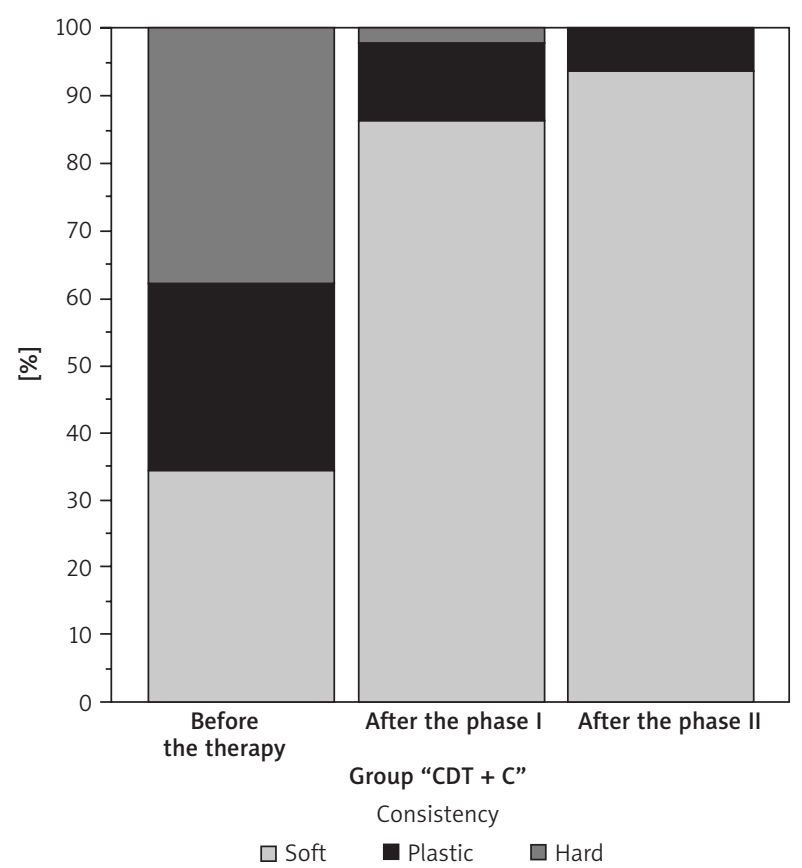

Figure 2. Consistency of lymphoedema in the study group in the course of the therapy

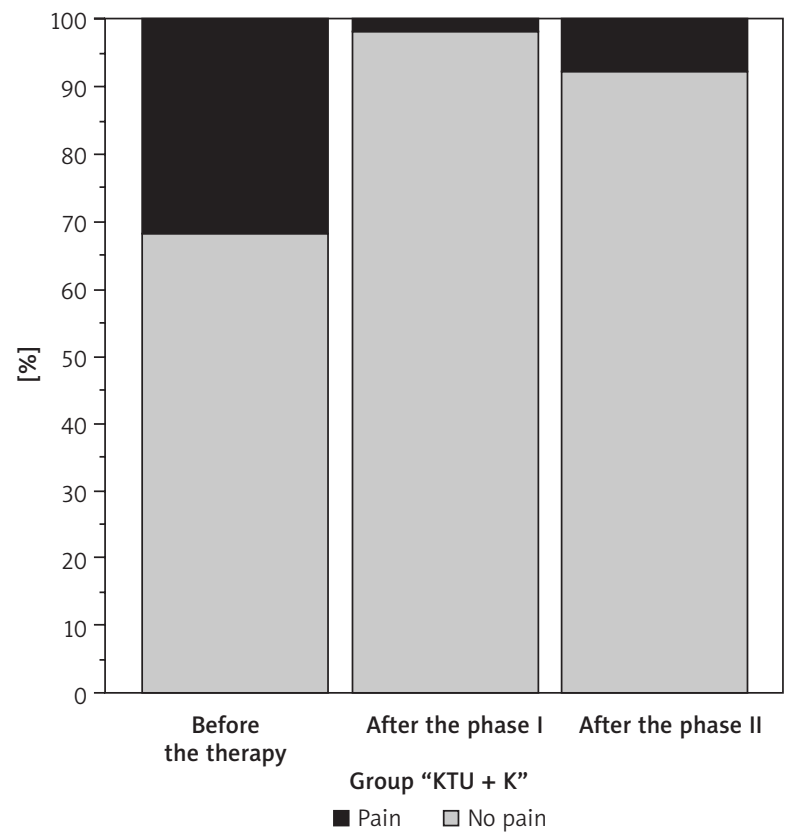

Figure 4. Symptoms of pain in the course of the treatment in the first group

after the first phase of the therapy, but after phase II it was reported by $4(8 \%)$ patients. In turn, in the second group, pain in the limb occurred after the first stage of the treatment in 4 (13\%), and after phase II in 3 (10\%) patients (Figures 4 and 5).

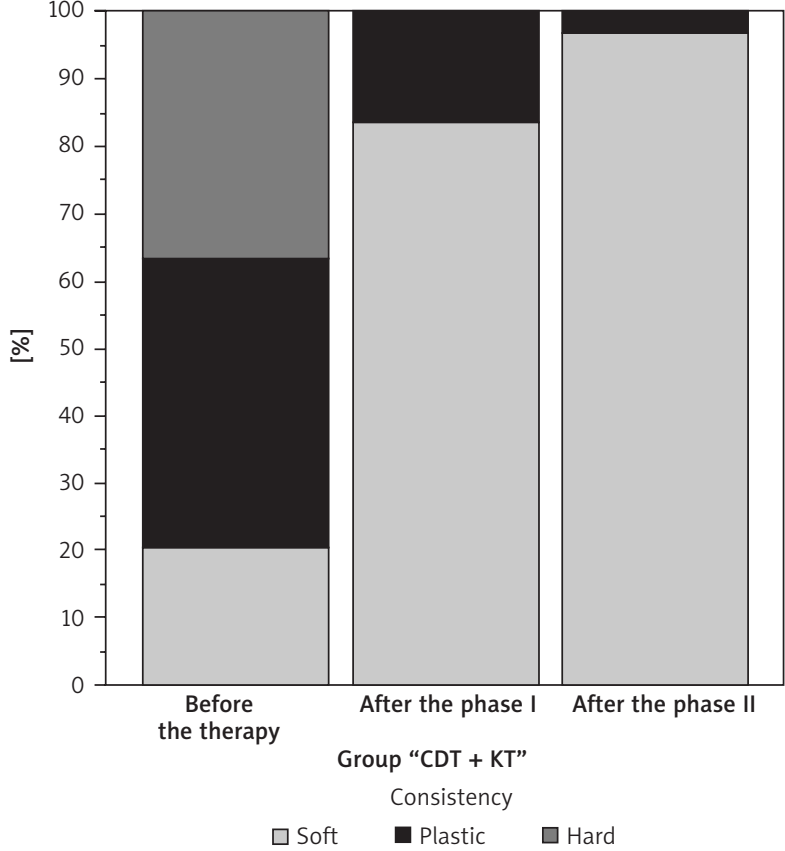

Figure 3. The consistency of oedema in the second group during the treatment

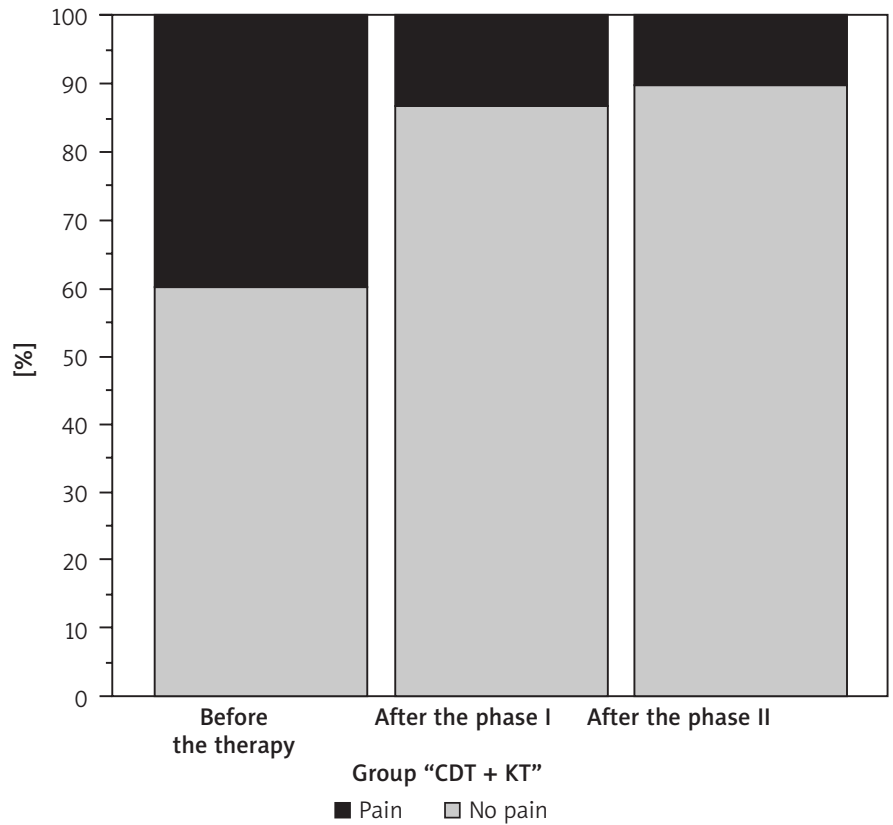

Figure 5. Symptoms of pain during the treatment in the second group

\section{Conclusions}

The applied antiedematous prophylaxis had no significance in the course of the treatment. Introduction of radiotherapy in the treatment of breast cancer had a significant impact on the state of oedema, 
particularly in the distal parts of the upper limb. Application of comprehensive physiotherapeutic management resulted in the reduction of the average circumferences of the upper limb, a favourable change in the consistency of the tissue, and a reduction in pain in all the patients after phase I of the therapy. Maintenance and improvement of the therapy results in phase II show the relevance of the systematic use of compression sleeves. Lymphatic application of KT does not guarantee a decrease in the state of the limb circumferences in phase II of the treatment, but it has a positive impact on the maintenance of the proper oedema consistency and reduction of pain. They can be an alternative for compression sleeves not accepted by patients.

\section{References}

1. Földie E. Coprehensive lymphedema treatment center. Lymphology 1994; 27: 505-7.

2. Casley-Smith JR Treatment for lymhedema of the arm the Casley-Smith method. Cancer 1998; 83: 2843-60.

3. Hwang JM, Hwang JH, Kim TW, et al. Long-term effects of complex decongestive therapy in breast cancer patients with arm lymhedema after axillary dissection. Ann Rehabil Med 2013; 37: 690-7.

4. Opuchlik A, Migórska A, Dudkiewicz Z, et al. Przydatność metody Kompleksowej Fizycznej Terapii Udrażniającej w leczeniu obrzęku limfatycznego kończyny górnej u kobiet po mastektomii [Polish]. Ortop Quart 2008; 4: 412-22.

5. Doś J. A doctoral dissertation. Ocena skuteczności manualnego drenażu limfatycznego i terapii uciskowej w leczeniu obrzęku kończyny górnej u kobiet po operacji raka piersi [Polish]. Pomorska Medical Academy, Szczecin 2008.

6. Vignes S, Porcher R, Arrault M, Dupuy A. Long-term management of breast cancer-related lymphedema after intensive decongestive physiotherapy. Breast Cancer Res Treat 2007; 101: 285-90.

7. Ko DS, Lerner R, Cosmi AB. Effective treatment of lymphedema of the extremities, Arch Surg 1998; 133: 452-8.

8. Vignes S, Porcher R, Arrault M, Dupuy A. Factors influencing breast cancer-related lymphedema volume after intensive decongestive physiotherapy. Support Care Cancer 2011; 19: 935-40

9. Vignes S, Porcher R, Champagne A, Dupuy A. Predictive factors of response intensive decongestive physiotherapy in upper limb lymphedema after breast cancer treatment: a short study. Breast Cancer Res Treat 2006; 98: 1-6.

10. Tsai HJ, Hung HC, Yang JL, et al. Could Kinesio Tape replace the bandage in decongestive lymphatic therapy for breast-cancer-related lymphodema. A pilot study. Support Care Cancer, Springer-Verlag 2009; 17: 1353-60.

11. Ciesielska N, Sokołowski R, Klimkiewicz K, et al. Comparison of effectiveness in application of manual lymphatic drainage and Kinesiology Taping with patients suffering post mastectomy lymphedema. Medical and Biological Sciences 2012; 26: 17-21.

12. Lipińska A, Śliwiński Z, Kiebzak W, et al. Wpływ aplikacji kinesiotapingu na obrzęk limfatyczny kończyny górnej u kobiet po mastektomii [Polish]. Fizjoter Pol 2007; 7: 258-69.

13. Pop T, Kaczmarek-Borkowska B, Tymczak M, et al. The influence of Kinesiology Taping on the reduction of lymphedema among women after mastectomy - preliminary study. Contemp Oncol (Pozn) 2014; 18: 124-9.

14. Woźniewski M, Majewski M, Szuba A, et al. The effect of physical exercise on the function of the lymphatic system of the upper limb in women after breast cancer treatment. Onkol Pol 2010; 13: 15-22.

15. Doś J, Gutowski P, Górska-Doś M. Występowanie oraz czynniki ryzyka obrzęku chłonnego u kobiet po operacji raka piersi [Polish]. Yerabooks of Pomorska Medical Academy in Szczecin 2009; 55: 30-4.

16. Kopański Z, Zyznawska J, Pięta R, Tymendorf G. Ocena ryzyka rozwoju obrzęku limfatycznego kończyny górnej u kobiet poddanych rehabilitacji ruchowej po radykalnej mastektomii [Polish]. Przegl Lek 2008; 65: 233-6.

17. Dziura I, Grądalski T. Wiedza o czynnikach wyzwalających powstanie obrzęku chłonnego i stosowanie się do zaleceń profilaktycznych $\mathrm{u}$ chorych po mastektomii [Polish]. Medical Rehabilitation 2008; 12: 14-8.

18. Werner GT. Diagnostyka i leczenie obrzęku limfatycznego - fizykalna terapia przeciwzastoinowa [Polish]. Reh Med 2002; 6: 57-61.

19. Majewski M. Fizjoterapia kobiet z obrzękiem chłonnym kończyny górnej po leczeniu raka sutka [Polish]. Fizjoterapia 2006; 14: 60-8.

20. Földie M, Strossenreuther R. Podstawy manualnego drenażu limfatycznego [Polish]. Woźniewski M (ed.). Partner \&Urban, Wrocław 2010; 32-3.

21. Földi M, Kubik S. Lehrbuch der Lyphologie, Gustav Fisher Verlang, Stuttgart, Jena, New York, 1993; 276-7.

22. Brauer WJ, Herpertz U, Schuchardt C, Weissleder H. Zalecenia postępowania terapeutycznego - diagnostyka i leczenie obrzęku limfatycznego [Polish]. Reh Med 2005; 9: 59-62.

23. Opuchlik A, Biskup M, Włoch A, et al. Methods of physiotherapeutic management used in the treatment of secondary lymphoedema in the Holycross Cancer Centre in Kielce. Studia Medyczne 2014; 30: 123-30.

\section{Address for correspondence}

Anna M. Opuchlik MD, PhD

The Holycross Cancer Center

ul. S. Artwińskiego 3, 25-734 Kielce, Poland

Phone: +48606713588

E-mail: annaop7@wp.pl 